\title{
Effect of a nanotechnology-based foliar fertilizer on the yield and fruit quality in an apple orchard
}

\author{
Csihon, Á., Gonda, I. \& Holb. I. J. \\ University of Debrecen, Faculty of the Agricultural and Food Sciences and Environmental Management, \\ Institute of Horticulture, 138. Böszörményi str., Debrecen, H-4032, Hungary \\ Author for correspondence: csihonadam@agr.unideb.hu
}

\begin{abstract}
Summary: Nutrient management is a determining element of the technology in fruit production. Significance of foliar fertilization has been increased continuously over the last years, as it can improve directly the vegetative and generative performance of the trees. In this study we aimed to evaluate the effect of a nanotechnology-based foliar fertilizer (Bistep) with 1, 3, and $51 /$ ha dosages on the yield and fruit quality parameters in an apple orchard during 2016 and 2018. According to our results, crop load increased with $29 \%$ in the third year of the experiment with the application of $5 \mathrm{l} / \mathrm{ha}$ Bistep treatment compared to the control treatments. Fruit weight was also improved in each year, as values of fruit weight in all treatments were higher than the control one (3.0-13.0\% growth). Fruit surface color increased with 2-18\% due to the foliar fertilizer. During the three years, leaf length was 9.5-9.9 $\mathrm{mm}$ on the control trees, as 9.8-10.4 $\mathrm{mm}$ was measured on the fertilized ones. In conclusion, yield and fruit quality can be improved in apple orchard using a nanotechnology-based foliar fertilizer.
\end{abstract}

Csihon, Á., Gonda, I., Holb, I. J. (2021): Effect of a nanotechnology-based foliar fertilizer on the yield and fruit quality in an apple orchard. International Journal of Horticultural Science 27: 29-32. https://doi.org/10.31421/ijhs/27/2021/9809

Key words: plant nutrition, foliar fertilizer, nanotechnology, apple, yield, fruit quality

\section{Introduction}

Fertilization of fruit trees is an essential element of the technology due to its significant influence on the quality and quantity of the yield. Nowadays foliar fertilization has become a basic management tool in the intensive orchards. Foliar fertilizers have an interesting potential to improve yield and fruit quality, with relatively low costs and low environmental impact. Application of sprays supplies nutrients to plants more rapidly than the soil fertilization (Tagliavini et al., 2002; Nagy, 2012).

The role of biostimulators is increasing all over the world. Biostimulators can be considered as natural growth regulators, they can contain plant hormones as auxin, gibberellic acid, cytokinins and aminoacids, orsome of them contain additive macro and micro nutrients. These preparations increase physiological activities in plants, first of all protein synthesis (Stampar et al., 2003; Nagy et al., 2012). Beneficial effect of the biostimulators on the yield and fruit quality is confirmed by several studies (Hudina et al., 2003; Solar, 2003; Basak \& Mikos-Bielak, 2008; Błaszczyk, 2008; Nagy et al., 2009; Csihon et al., 2013).

Researches all over the word focus on developing new technologies which can help the more effective production. Nanotechnology currently belongs to the most promising areas, which has leaped huge achievements during the last decades (Yao et al., 2013; Rao \& Gan, 2015; Singh et al., 2016). The technology is based on the synthesis and modulation of nanoparticles, where the molecular are on the nanoscale, typically smaller than $100 \mathrm{~nm}$ (Abraham et al., 2008; Auffan et al., 2009). The new properties of nanoscale particles ensure useful functions that are being rapidly exploited in e.g. energy sectors, electronics, material science, medicine and biotechnology (Parisi et al., 2015). In agriculture, nanotechnology is mainly used to increase food production, aiming to achieve high nutritional value, quality and safety. It can facilitate the transformations of traditional food and agriculture sectors with the utilisation of nanopesticides, nanofertilizers, nanosensors and active packaging (Rao \& Gan, 2015; He et al., 2018). Nanotechnology is widely used in modern agriculture to help the spread of precision agriculture (Duhan et al., 2017).

Nanomaterials in crop production aim among others to minimize nutrient losses in fertilization and increase yields by optimized water and nutrient management (Gogos et al., 2012). Nanofertilizers balances the release of main macroelements with their absorption by the plant, as nutrient losses can be prevented and unwanted nutrients interaction with microorganisms, water and air can be avoided (Emadian, 2017). Furthermore nanotechnology is suitable also for helping the availability of micronutrients to plants (Peteu et al., 2010).

The aim of this work was to provide data on the effect of three concentrations of nanotechnology-based biostimulator on the yield and fruit quality in an apple orchard.

\section{Materials and methods}

\section{Experimental site}

The study was performed at the Horticultural Experimental Farm of University of Debrecen from 2016 to 2018. Type of the soil is light sandy loam, the $\mathrm{pH}$ of soil is slightly alkaline (pH 7.5-7.6). Humus content varies between 1.2 and $1.6 \%$, the "Arany" number of heaviness is 26-28. 
The apple orchard was planted in spring of 2011. Trees were grafted on M.9 rootstock and designed with spacing of 4 $\mathrm{x} 1$ meter. Trees were trained to slender spindle with the height of $3.5 \mathrm{~m}$. The study was performed on cultivar 'Pinova'. Orchard has drip irrigation system. Plant protection refers to the principles of integrated pest management.

\section{Applied treatments}

The main objective of this study was to evaluate the effect of a nanotechnology-based biostimulator (Bistep) on the yield and fruit quality in an apple orchard. The trial was consisted of four treatments (control, 1, 3 and 5 1/ha concentrations). First treatment was applied at full bloom in each year, then treatments were repeated 6-7 times (Table 1). Each treatment was consisted of 10 trees.

Table 1. Time of treatments (Debrecen, Pallag, 2016-2018)

\begin{tabular}{|c|c|c|}
\hline $\mathbf{2 0 1 6}$ & $\mathbf{2 0 1 7}$ & $\mathbf{2 0 1 8}$ \\
\hline 14 April & 5 April & 9 April \\
\hline 27 April & 26 April & 25 April \\
\hline 23 May & 10 May & 17 May \\
\hline 6 June & 25 May & 31 May \\
\hline 22 June & 12 June & 19 June \\
\hline 7 July & 29 June & 6 July \\
\hline 27 July & 3 August & 31 July \\
\hline 10 August & & \\
\hline
\end{tabular}

\section{Applied materials}

'Pinova' is a German apple cultivar, hybrid of 'Clivia' and 'Golden Delicious'. It has high fruit yield, with little tendency towards biennial bearing. It is tolerant to the scab, but sensitive to powdery mildew. Fruit is juicy and crisp, red skin color is about 50-70\% (Fischer et al., 2000).

Bistep is a nanotechnology-based plant conditioner preparation (Manufacturer: UAB ALJARA, LT-11219 Vilnius, Geniu Str. 16-38., Lithuania). It contains microhumatates, macronutrients, active salts of organic acids, amino acids, fulvic acid, vitamins, phytohormones, soil microflora and trace elements (Table 2). The main active ingredients, microhumatates are formed by physical disassembly of natural humic substances.

Table 2. Active ingredients of Bistep

\begin{tabular}{|l|c|}
\hline Parameter & Value \\
\hline Dry matter content (w/w\%) & 1.3 \\
\hline Organic matter content (w/w\%) d.m. & 25 \\
\hline $\mathrm{N}$ content $(\mathrm{w} / \mathrm{v} \%)$ & 0.02 \\
\hline $\mathrm{P}_{2} \mathrm{O}_{5}$ content $(\mathrm{w} / \mathrm{v} \%)$ & 0.03 \\
\hline $\mathrm{K}_{2} \mathrm{O}$ content $(\mathrm{w} / \mathrm{v} \%)$ & 0.3 \\
\hline $\mathrm{MgO}$ content $(\mathrm{w} / \mathrm{v} \%)$ & 0.02 \\
\hline $\mathrm{B}$ content $(\mathrm{w} / \mathrm{v} \%)$ & 0.0002 \\
\hline Fe content $(\mathrm{w} / \mathrm{v} \%)$ & 0.01 \\
\hline
\end{tabular}

\section{Assessed parameters}

During harvest, fruit yield ( $\mathrm{kg} / \mathrm{tree})$ was measured. For the better comparability these data were compared also to the trunk thickness and expressed as crop load $\left(\mathrm{kg} / \mathrm{cm}^{2}\right)$. Fruit quality parameters were assessed based on 100 fruits/treatments.
Diameter (mm) and weight $(\mathrm{g})$ of the fruits were determined. Fruit surface color was evaluated with a visual estimation in percentage form. The intensity (darkness) of the fruit surface color was assessed with similar method on a scale ranging from 1-5. Leaf size (length, width) was measured based on 100 leaves/treatments. Two parameters of the leaf size were multiplied, which is proportional to the leaf area. Statistics were performed by ANOVA at $\mathrm{P}=0.05$ level using LSD test.

\section{Results and discussion}

Effect of the treatments on the yields is concluded in Table 3. Data shows that the lowest yield was harvested from the control trees in each year (21.9-33.4 kg/tree). Crop load (yield/trunk thickness) was also the lowest with the untreated trees $\left(0.64-0.92 \mathrm{~kg} / \mathrm{cm}^{2}\right)$, while sprayed trees presented values between 0.62 and $1.14 \mathrm{~kg} / \mathrm{cm}^{2}$.

Crop load of the fertilized trees was nearly equal in 2018 $\left(1.08-1.19 \mathrm{~kg} / \mathrm{cm}^{2}\right)$, the highest value was observed for $5 \mathrm{l} / \mathrm{ha}$ treatment $\left(1.19 \mathrm{~kg} / \mathrm{cm}^{2}\right)$, while data of control trees was lower with $29 \%\left(0.92 \mathrm{~kg} / \mathrm{cm}^{2}\right)$. However, this notable difference is presumably due not only to the treatments performed in 2018 , but also to the fact that this was the third consecutive year that the trees received plant conditioner.

Table 3. Fruit yield and crop load (Debrecen - Pallag, 2016-2018)

\begin{tabular}{|l|c|c|c|c|c|c|}
\hline & \multicolumn{3}{|c|}{ Fruit yield (kg/tree) } & \multicolumn{3}{c|}{ Crop load (kg/cm $\left.{ }^{2}\right)$} \\
\hline & $\mathbf{2 0 1 6}$ & $\mathbf{2 0 1 7}$ & $\mathbf{2 0 1 8}$ & $\mathbf{2 0 1 6}$ & $\mathbf{2 0 1 7}$ & $\mathbf{2 0 1 8}$ \\
\hline Control & 21.9 & 21.7 & 33.4 & 0.79 & 0.64 & 0.92 \\
\hline $\mathbf{1}$ l/ha & 23.0 & 33.5 & 39.4 & 0.96 & 1.01 & 1.14 \\
\hline $\mathbf{3}$ l/ha & 29.5 & 22.2 & 37.8 & 1.11 & 0.62 & 1.08 \\
\hline $\mathbf{5}$ l/ha & 26.3 & 28.8 & 51.5 & 0.84 & 0.73 & 1.19 \\
\hline$L S D_{5 \%}$ & 7.2 & 6.6 & 8.3 & 0.25 & 0.21 & 0.36 \\
\hline
\end{tabular}

Fruit size was between 76 and $78 \mathrm{~mm}$ in the first two year, while in 2018 diameter changed between $72-75 \mathrm{~mm}$ (Table 4). Differences are more evident regarding fruit weight, as treatments resulted in 3.0-13.0\% increase in 2016 (206-224 g), compared to the control $(200 \mathrm{~g})$. The largest fruits were picked in $5 \mathrm{l} / \mathrm{ha}$ treatment $(224 \mathrm{~g})$. In 2017 , fruit weight was larger with $3.6-5.2 \%(201-204 \mathrm{~g})$ for $3 \mathrm{l} / \mathrm{ha}$ and $5 \mathrm{l} / \mathrm{ha}$ treatments, compared to the untreated trees (194 g). In 2018, fruit size of the control trees was $72.3 \mathrm{~mm}$, while fruits of the sprayed ones ranged from 73.1 to $75.1 \mathrm{~mm}$.

Table 4. Fruit size and fruit weight (Debrecen - Pallag, 2016-2018)

\begin{tabular}{|l|c|c|c|c|c|c|}
\hline & \multicolumn{3}{|c|}{ Fruit size (mm) } & \multicolumn{3}{c|}{ Fruit weight (g) } \\
\hline & $\mathbf{2 0 1 6}$ & $\mathbf{2 0 1 7}$ & $\mathbf{2 0 1 8}$ & $\mathbf{2 0 1 6}$ & $\mathbf{2 0 1 7}$ & $\mathbf{2 0 1 8}$ \\
\hline Control & 78.6 & 78.4 & 72.3 & 200 & 194 & 160 \\
\hline $\mathbf{1}$ l/ha & 78.8 & 75.7 & 73.1 & 206 & 192 & 163 \\
\hline $\mathbf{3}$ l/ha & 76.2 & 76.9 & 75.1 & 211 & 201 & 179 \\
\hline $\mathbf{5}$ l/ha & 78.2 & 77.8 & 73.8 & 224 & 204 & 168 \\
\hline
\end{tabular}

The most spectacular changes can be seen in the coloration of the fruits (Table 5), as Bistep treatments had unequivocal positive effect on the fruit surface colour and fruit colour intensity in each year. In 2016, fruit surface colour of control trees was $29 \%$, while surface colouration of sprayed fruits was $45-53 \%$. One year later colour improvement compared to the 
control varied up $2 \%$ to $10 \%$ due to the treatments. In 2018 , untreated trees presented only $31 \%$ skin coloration, while foliar fertilizing resulted in 46-49\% fruit surface colour.

In the case of the fruit color intensity, which means the darkness of the red color, untreated trees presented also the lowest values. During three years fruits of control trees produced weaker coloration on a scale ranging from 1-5 fruits presented values between 2.9-3.1, while fertilized fruits reached values of 3.9-4.6.

Table 5. Fruit surface colour and fruit colour intensity (Debrecen - Pallag, 2016-2018)

\begin{tabular}{|l|c|c|c|c|c|c|}
\hline & \multicolumn{4}{|c|}{ Fruit surface colour (\%) } & \multicolumn{3}{c|}{$\begin{array}{c}\text { Fruit colour intensity } \\
(\mathbf{1 - 5})\end{array}$} \\
\hline & $\mathbf{2 0 1 6}$ & $\mathbf{2 0 1 7}$ & $\mathbf{2 0 1 8}$ & $\mathbf{2 0 1 6}$ & $\mathbf{2 0 1 7}$ & $\mathbf{2 0 1 8}$ \\
\hline Control & 29 & 37 & 31 & 3.1 & 3.7 & 2.9 \\
\hline $\mathbf{1}$ l/ha & 45 & 39 & 46 & 4.0 & 3.9 & 4.4 \\
\hline $\mathbf{3}$ l/ha & 47 & 40 & 49 & 4.4 & 4.0 & 4.3 \\
\hline $\mathbf{5}$ l/ha & 53 & 50 & 47 & 4.4 & 4.6 & 4.5 \\
\hline
\end{tabular}

Leaf size is a determining factor regarding the assimilation performance of the trees (Table 6). Data shows that leaf length and leaf width were increased by the treatments in each year. During 3 years leaf length was 9.5-9.9 $\mathrm{mm}$ on the control trees, as $9.8-10.4 \mathrm{~mm}$ was measured on the fertilized ones. Leaf width varied between 5.1 and $5.4 \mathrm{~mm}$ for the untreated trees, while fertilized trees presented 5.8-6.2 mm values. When the two parameters are multiplied, it can be seen that $51 /$ ha Bistep treatment caused $7.4 \%$ increase (61.0) in leaf area compared to the control (56.8).

Table 6. Leaf size (Debrecen - Pallag, 2016-2018)

\begin{tabular}{|l|c|c|c|c|c|c|c|c|c|}
\hline & \multicolumn{3}{|c|}{ Length (cm) } & \multicolumn{3}{c|}{ Width (cm) } & \multicolumn{3}{c|}{$\begin{array}{c}\text { Length(cm) } \\
\text { width(cm) }\end{array}$} \\
\hline & $\mathbf{2 0 1 6}$ & $\mathbf{2 0 1 7}$ & $\mathbf{2 0 1 8}$ & $\mathbf{2 0 1 6}$ & $\mathbf{2 0 1 7}$ & $\mathbf{2 0 1 8}$ & $\mathbf{2 0 1 6}$ & $\mathbf{2 0 1 7}$ & $\mathbf{2 0 1 8}$ \\
\hline Control & 9.5 & 9.9 & 9.8 & 5.1 & 5.9 & 5.8 & 49.0 & 58.8 & 56.8 \\
\hline $\mathbf{1}$ l/ha & 9.6 & 9.8 & 9.7 & 5.4 & 5.9 & 5.8 & 51.6 & 57.5 & 56.3 \\
\hline $\mathbf{3 ~ 1 / h a}$ & 9.6 & 10.4 & 9.9 & 5.2 & 6.2 & 5.9 & 49.9 & 64.1 & 58.4 \\
\hline $\mathbf{5}$ l/ha & 9.9 & 10.3 & 10.0 & 5.2 & 6.0 & 6.1 & 50.8 & 62.2 & 61.0 \\
\hline
\end{tabular}

\section{Conclusions}

Based on our study, it can be stated that yield and fruit quality can be improved effectively in apple orchard using nanotechnology-based foliar fertilizer. During three years, crop load increased with $29 \%$ in 5 1/ha Bistep treatment. Fruit size and weight were also improved, as values of all treatments were higher than the control. Fruit surface color increased with $2-18 \%$ due to the plant conditioner.

\section{Acknowledgements}

The publication is supported by the EFOP-3.6.1-16-201600022 project. The project is co-financed by the European Union and the European Social Fund. The study was also supported by the Thematic Excellence Programme of the Ministry for Innovation and Technology in Hungary (TKP2020-NKA-04), within the framework of the climate change thematic programme of the University of Debrecen.

\section{References}

Abraham, A., Kannangai, R., Sridharan, G., (2008): Nanotechnology: a new frontier in virus detection in clinical practice. Indian J. Med. Microbiol. 26(4) 297-301.

Auffan, M., Rose, J., Bottero, J. Y., Lowry, G. V., Jolivet, J. P., Wiesner, M. R. (2009): Towards a definition of inorganic nanoparticles from an environmental, health and safety perspective. Nat. Nanotechnology 4. 634-664.

Baptista, F. R., Belhout, S. A., Giordani, S., Quinn, S. J. (2015): Recent developments in carbon nanomaterial sensors. Chem. Soc. Rev. 44(13): 4433-4453.

Basak, A., Mikos-Bielak, M. (2008): The use of some biostimulators on apple and pear trees. In: Z.T. Dabrowski (ed.): Biostimulators in modern fruit agriculture. 7-17.

BHaszczyk, J. (2008): Quality of 'Conference' pears as affected by Goëmar BM 86 and Fruton. In: Biostimulators in modern agriculture: Fruit crops. Ed.: Dabrowski, Z. T.) 18-24.

Csihon, Á., Illés, A., Szabó, A., Bicskei, D. K. (2013): Biostimulátor készítmények összehasonlító vizsgálata intenzív almaültetvényben. Kertgazdaság 45(4): 20-27.

Duhan, J. S., Kumar, R., Kumar, N., Kaur, P., Nehra, K., Duhan, S. (2017): Nanotechnology: The new perspective in precision agriculture. Biotechnology Reports 15. 11-23.

Emadian, S. E. (2017): Physiological Responses of Loblolly Pine (Finustaeda L.) to Silicon and Water Stress, Texas A \&M Univ, college station, TX, 2017, pp. 27-37 (Ph.D. Thesis, Diss. Abst.AAC8815865).

Fischer, H. M., Schmadlak, J., Fischer, C. M. (2000): Apple Tree Named 'Pinova'. United States Patent. Pub. $\mathrm{N}^{\circ}$.: US00PP11601P. Patent Number: 11,601

Ghormade, V., Deshpande, M. V., Paknikar, K. M., (2011): Perspectives for nano-biotechnology enabled protection and nutrition of plants. Biotechnol. Adv. 29. 792-803. https://doi.org/10.1016/j.biotechadv.2011.06.007.

Gogos, A., Knauer, K., Bucheli, T. D. (2012): Nanomaterials in Plant Protection and Fertilization: Current State, Foreseen Applications, and Research Priorities. J. Agric. Food Chem. 60. 9781-9792. https://doi.org/10.1021/jf302154y

He, X., Deng., H., Hwang, H. (2018): The current application of nanotechnology in food and agriculture. Journal of Food and Drug Analysis 27. 1-21. https://doi.org/10.1016/j. jfda.2018.12.002

Hudina, M., Solar, A., Stampar, F. (2003): Does foliar nutrition influence the pear fruit quality? International Journal of Horticultural Science. 9(2): 25-28. https://doi.org/10.31421/ IJHS/9/2/386

Khot, L. R., Sankaran, S., Maja, J. M., Ehsani., S., Schuster, S. W. (2012): Applications of nanomaterials in agricultural production and crop protection: A review. Crop Prot. 35. 64-70. https://doi.org/10.1016/j.cropro.2012.01.007

Nagy, P. T. (2012): Bioregulátor kísérletek eredményei és gyakorlati hasznosítási tapasztalatai a gyümölcstermesztésben. Debreceni Egyetem. AGTC MK Kertészettudományi Intézet. 97 p.

Nagy, P. T., Ambrus, A., Nyéki, J., Soltész, M., Szabó, Z. (2012): Effect of foliar spraying with algae suspension on leaf and fruit quality parameters of apple varieties. International 
Journal of Horticultural Science. 18(1): 35-38. p. https://doi.org/10.31421/IJHS/18/1/991

Nagy, P. T., Csihon, Á., Szabó, A. (2019): Effects of algae products on nutrient uptake and fruit quality of apple. National resources and sustainable development 9(1): 80-91. p. https://doi.org/10.31924/nrsd.v9i1.026

Parisi, C., Vigani, M., Rodríguez-Cerezo, E. (2015): Agricultural Nanotechnologies: What are the current possibilities? Nano Today 10. 124-127. p. https://doi.org/10.1016/j.nantod.2014.09.009

Peteu, S.F., Oancea, F., Sicuia, O.A., Constantinescu, F., Dinu, S. (2010): Responsive polymers for crop protection. Polymers 2(3): 229-251. https://doi.org/10.3390/ polym 2030229

Rao, P. V., Gan, S. H. (2015): Recent advances in nanotechnology-based diagnosis and treatments of diabetes. Curr. Drug Metab.16, 371-375. https://doi.org/10.2174/ 1389200215666141125120215

Santoso, D., Lefroy, R.D.B., Blair, G. J. (1995): Sulfur and phosphorus dynamics in an acid soil/crop system. Aust. J. Soil Res. 33. 113-124. https://doi.org/10.1071/SR9950113

Shojaei, T. B., Salleh, M. A. H., Tabatabaei, M., Mobli, H., Aghbashlo, M., Rashid, S. A., Tan, T. (2019): Applications of Nanotechnology and Carbon Nanoparticles in Agriculture. In Micro and Nano Technologies, Synthesis, Technology and Applications of Carbon Nanomaterials, Editor(s): Rashid, S. A., Othman, R. N. I. R., Hussein, M. Z. 247-277. p. https://doi.org/10.1016/B978-0-12-815757-2.00011-5.

Sing, P., Kim, Y. J., Zhang, D., Yang, D. C. (2016): Biological Synthesis of Nanoparticles from Plants and
Microorganisms. Trends in Biotechnology 34(7): 588-599. p. https://doi.org/10.1016/j.tibtech.2016.02.006

Solar, A. (2003): The effects of foliar nutrition containing various macro and microelements on the growth and development of young grafted walnut (Juglans regia L.) plants. International Journal of Horticultural Science, 9(2): 33-37. https://doi.org/10.31421/IJHS/9/2/388

Stampar, F., Solar, A., Hudina, M. (2003): Influence of foliar nutrition on apple production. International Journal of Horticultural Science. 9(2): 15-18. https://doi.org/10.31421/ IJHS/9/2/384

Tagliavini, M., Drahorad, W., Dalla Via, J. (2002): Preface. Acta Horticulturae 594. https://doi.org/10.17660/ActaHortic. 2002.594.

Zheng, L., Hong, F., Lu, S., Liu, C. (2005): Effect of nano$\mathrm{TiO}(2)$ on strength of naturally aged seeds and growth of spinach. Biol. Trace Elem. Res. 104. 83-91. https://doi.org/10.1385/BTER:104:1:083

Yao, D., Chena, Z., Zhao, K., Yang, Q., Zhang W. (2013): Limitation and challenge faced to the researches on environmental risk of nanotechnology. 2013 International Symposium on Environmental Science and Technology. 149156. p. https://doi.org/10.1016/j.proenv.2013.04.020

Wilson, M.A., Tran, N.H., Milev, A.S., Kannangara, G.S.K., Volk, H., Lu, G.Q.M., (2008): Nanomaterials in soils. Geoderma 146. 291-302. https://doi.org/10.1016/j.geoderma. 2008.06.004 